6. Haber GB. Tissue glue for pancreatic fistula. Gastrointest Endosc 2004; 59:535-7.

7. Vallieres E, Jamieson C, Haber GB, Mackenzie RL. Pancreaticoduodenal necrosis after endoscopic injection of cyanoacrylate to treat a bleeding duodenal ulcer: a case report. Surgery 1989;106:901-3.

8. Cheah WK, So J, Chong SM, Goh P. Duodenal ulcer perforation following cyanoacrylate injection. Endoscopy 2000;32:S23.

9. Lin $\mathrm{HJ}$, Hsieh $\mathrm{YH}$, Tseng GY, Perng CL, Chang FY, Lee SD. A prospective, randomized trial of large- versus small-volume endoscopic injection of epinephrine for peptic ulcer bleeding. Gastrointest Endosc 2002;55: 615-9.
Division of Gastroenterology, Department of Medicine, National University Hospital, Singapore.

Reprint requests: Chun Tao Wai, MBBS, MRCP, Division of Gastroenterology, Department of Medicine, National University Hospital, 5 Lower Kent Ridge Rd., Singapore 119074.

Copyright $\odot 2005$ by the American Society for Gastrointestinal Endoscopy $0016-5107 / 2005 / \$ 30.00+0$

PII: S0016-5107(04)02838-X

\title{
Endoscopic appearance of GI mycobacteriosis caused by the Mycobacterium avium complex in a patient with AIDS: case report and review
}

\author{
Hsin-Yun Sun, MD, Mao-Yuan Chen, MD, Ming-Shiang Wu, MD, PhD, Szu-Min Hsieh, MD, \\ Chi-Tai Fang, MD, PhD, Chien-Ching Hung, MD, Shan-Chwen Chang, MD, PhD
}

Taipei, Taiwan

Disseminated Mycobacterium avium complex (MAC) infection, an important AIDS-defining opportunistic infection in patients with advanced HIV infection (generally those with $\mathrm{CD} 4$ lymphocyte counts $<50$ cells $/ \mu \mathrm{L}$ ), is associated with significant morbidity and mortality, and with shortened survival. ${ }^{1,2}$ The incidence of disseminated MAC (DMAC) infection increased during the period 1982 to 1994, with the maturation of the AIDS epidemic, ${ }^{3}$ to an estimated cumulative incidence of $15 \%$ to $24 \%$ of patients with AIDS. ${ }^{4}$ With the introduction of antimicrobial prophylaxis and highly active antiretroviral therapy (HAART), the incidence of DMAC infection dramatically declined and survival improved. ${ }^{5}$ According to the U.S. Centers for Disease Control and Prevention, the incidence of DMAC infection decreased from 10 cases per 100 person-years in 1992 to two cases per 100 person-years in $1998 .{ }^{6}$ Survival increased from 40 days before the introduction of HAART to 398 days in the post-HAART era. ${ }^{3}$ Despite advances in the care of patients with AIDS and MAC infection, new or recurrent DMAC infection continues to occur in patients with limited access to care for HIV infection and in those who do not respond to antiretroviral therapy. ${ }^{3,7,8}$ The GI tract appears to be a common portal of entry for MAC infection in patients with AIDS. Local replication may result in the formation of local foci with subsequent dissemination via lymphatics within months. ${ }^{9}$ A case of AIDS with endoscopic finding of MAC infection of the duodenum is presented. Reported cases that include an endoscopic description are reviewed, with the aim of improving early recognition of MAC infection in the GI tract.

\section{CASE REPORT}

The patient, a 42-year-old, homosexual man with HIV infection diagnosed 6 years earlier, presented with a 2-month history of epigastric pain, abdominal bloating, and intermittent fever. Two months before hospitalization, the plasma viral load had rebounded and the CD4 count was 63 cells/ $\mu$ L despite HAART.

At the time of diagnosis of HIV infection, antiretroviral and prophylactic antimicrobial therapy was begun, but the patient did not continue this treatment, because of severe GI symptoms. Pneumocystis carinii pneumonia (PCP) and tuberculosis developed at 4 and 5 years, respectively, after the diagnosis of HIV infection, and the patient was treated with trimethoprim-sulfamethoxazole and antituberculosis therapy. However, he was not compliant with the prescribed therapy. Eight months before presentation, nontyphoid salmonellosis and recurrent PCP developed, and blood cultures subsequently grew MAC. HAART and antiMAC therapy (ciprofloxacin, clarithromycin, and ethambutol) were initiated. 

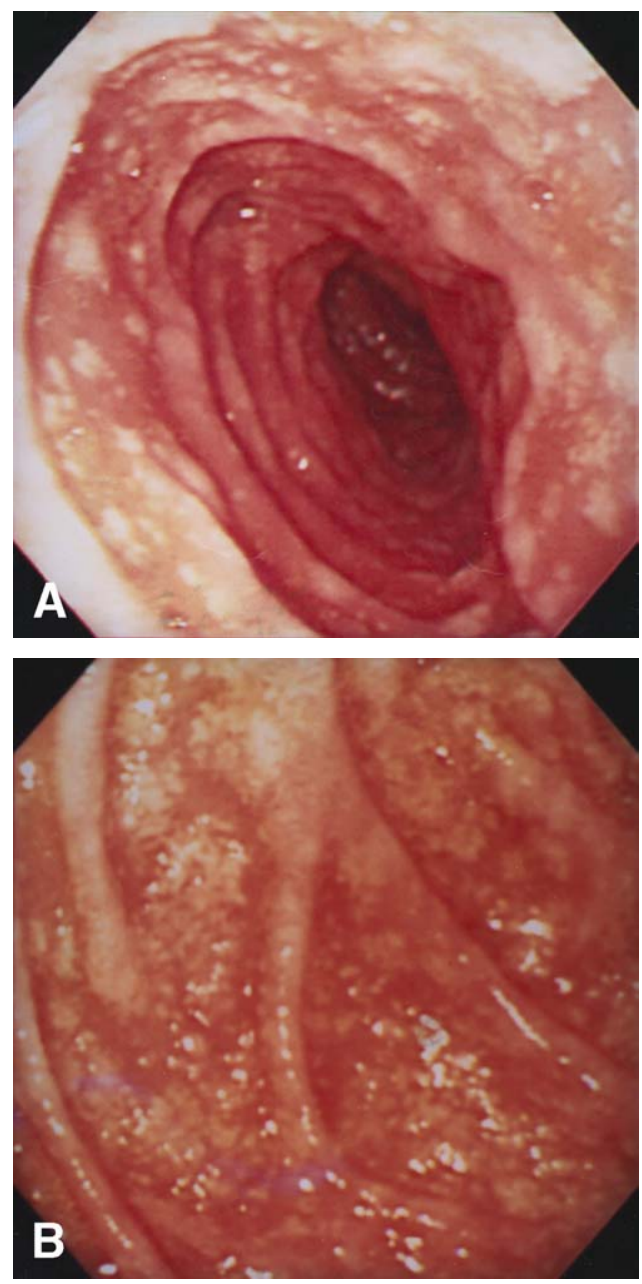

Figure 1. A, Endoscopic view showing scattered white nodules and plaques in second portion of duodenum. B, Magnified endoscopic view.

Examination revealed mild tenderness in the right and the left upper abdominal quadrants. The CD4 lymphocyte count was 41 cells $/ \mu \mathrm{L}$; the plasma viral load was undetectable $(<400$ copies/mL by reverse transcriptase-polymerase chain reaction). Computed tomography of the abdomen disclosed extensive lymphadenopathy in the para-aortic region and the bilateral adrenal glands, and also localized wall thickening of the jejunum. A liver biopsy, performed because of marked elevation of the serum level of alkaline phosphatase (1595 U/L, [normal: 60-220 U/L]) and $\gamma$ glutamyl transferase $(267 \mathrm{U} / \mathrm{L}, \quad[<52 \mathrm{U} / \mathrm{L}])$, revealed abundant acid-fast bacilli. No specific findings were noted at colonoscopy, but EGD disclosed diffuse, scattered white nodules and plaques in the second portion of the duodenum (Fig. 1). Cultures of blood and tissue obtained from biopsies of the liver and the duodenum all yielded MAC, despite maintenance therapy with ciprofloxacin, clarithromycin, and ethambutol. Although the symptoms gradually improved with continuation of anti-MAC treatment and HAART, the patient still complained of epigastric pain, abdominal bloating, and intermittent diarrhea.
The patient developed progressive dyspnea, urinary difficulty, and retention over several days, and was admitted to our hospital. The symptoms rapidly worsened on the first hospital day, with severe respiratory distress. Lactic acidosis developed, and the patient died on the day of admission, despite resuscitation.

\section{DISCUSSION}

Although opportunistic infection with MAC is common in patients with advanced HIV infection, there are few detailed endoscopic descriptions of MAC infection of the GI tract. A search of the MEDLINE database (English language publications) identified 54 reported cases of DMAC infection with involvement of the GI tract in patients with AIDS in which an endoscopic description was included. ${ }^{8,10-24}$ The demographic, clinical, and endoscopic features, and the outcome for the 55 cases (including the present case) are shown in Table 1 . Most reported cases predate the HAART era; only 3 patients received HAART. ${ }^{8,24}$ The median age of the patients was 32 years (range 14 months to 50 years). The common presenting symptoms included diarrhea (93\%), fever (89\%), weight loss (87\%), and abdominal pain (82\%). GI manifestations included gastric ulceration, enterocolitis, enteric fistulas, intra-abdominal abscess, and hemorrhage. ${ }^{4,21}$ Anemia, neutropenia, elevated alkaline phosphatase, hepatosplenomegaly, lymphadenopathy, and pneumonia also were observed, because dissemination to multiple organ systems was present in most of the patients. In the 55 reported cases of MAC infection of the GI tract, the duodenum (76\%) was the most common site, followed by the rectum (24\%), the ileum (6\%), the colon (4\%), the esophagus (4\%), the jejunum (2\%), and the stomach (2\%). The CD4 count at presentation was available in only 4 cases; the median CD 4 count was 41 cells/ $\mu \mathrm{L}$ (6-69 cells/ $\mu \mathrm{L}) .{ }^{8,15,23,24}$ Most patients died soon after the diagnosis of DMAC infection, despite antimycobacterial therapy. The high mortality rate for patients with GI DMAC infection is probably explained by the fact that only 3 patients received macrolide-containing treatment regimens and HAART.

Because patients with DMAC infection are in an advanced stage of HIV infection, concurrent GI infections may be present. Multiple pathogens, such as microsporidia, Cryptosporidium, Giardia, cytomegalovirus (CMV), and Isospora, have been identified by EGD in the duodenum of HIV-infected patients with chronic unexplained diarrhea. ${ }^{25}$ EGD findings may be nonspecific, with the exception of ulcerative lesions, which are frequent in CMV gastroduodenitis. ${ }^{26}$ In our review, the most common endoscopic finding was multiple raised nodules (38\%) in the involved sites. These nodules could be yellow, white, yellow-whitish, or pink. Although nodular lesions are frequent, ${ }^{9}$ endoscopy in patients with MAC infection of the GI tract may disclose normal findings (36\%), ulcerations (11\%), erythema (13\%), edema (11\%), friability (11\%), a reduced mucosal vascular pattern (9\%), erosions (4\%), confluent nodules (4\%), 
TABLE 1. Demographic, clinical and endoscopic findings and outcome for patients with AIDS and disseminated Mycobacterium avium complex infection with Gl-tract involvement

\begin{tabular}{|c|c|c|}
\hline Reference & $\begin{array}{c}\text { Age } \\
\text { y/gender }\end{array}$ & $\begin{array}{c}\text { Clinical } \\
\text { presentation }\end{array}$ \\
\hline Strom et $\mathrm{al}^{10}$ & $30 / M$ & $\begin{array}{l}\text { Spiking fever, diarrhea, } \\
\text { weakness, abdominal } \\
\text { pain secondary to } \\
\text { a massively enlarged } \\
\text { spleen }\end{array}$ \\
\hline
\end{tabular}

\begin{tabular}{|c|c|c|}
\hline Gillin et $\mathrm{al}^{11}$ & $39 / M$ & $\begin{array}{l}\text { Diarrhea, fever, weight } \\
\text { loss }\end{array}$ \\
\hline Caya et $\mathrm{al}^{12}$ & $32 / \mathrm{M}$ & $\begin{array}{l}\text { Diarrhea, weight loss, } \\
\text { fever }\end{array}$ \\
\hline Wolke et al $^{13}$ & $40 / M$ & $\begin{array}{l}\text { Abdominal pain, } \\
\text { bloody diarrhea }\end{array}$ \\
\hline Roth et al $^{14}$ & $30 / M$ & $\begin{array}{l}\text { Fever, diarrhea, weight } \\
\text { loss }\end{array}$ \\
\hline $\begin{array}{l}\text { Schneebaum } \\
\text { et } \mathrm{al}^{15}\end{array}$ & $38 / M$ & $\begin{array}{l}\text { Diarrhea, anorexia, } \\
\text { malaise, low-grade } \\
\text { temperature, weight loss }\end{array}$ \\
\hline
\end{tabular}

Vasquez-Iglesias $\quad 24 / F$ et $\mathrm{al}^{16}$

Gray and Rabeneck $^{17}$ 35 cases; mean $35.1 / \mathrm{M}$

\section{Connolly} et $\mathrm{al}^{18}$

\section{Monsour \\ et $\mathrm{al}^{19}$}

$\begin{array}{lll} & 30 / M & \begin{array}{l}\text { Fever, malaise, anorexia, } \\ \text { hepatosplenomegaly, } \\ \text { epigastric burning, } \\ \text { melena, weakness, } \\ \text { confusion }\end{array} \\ & & \begin{array}{l}\text { Watery diarrhea, fever, } \\ \text { abdominal pain, weight } \\ \text { loss }\end{array}\end{array}$

Diarrhea, weight loss, pruritis, mild asthenia, anorexia

Weight loss (30/35); 35); diarrhea (17/35); abdominal pain $(7 / 35)$

Persistent diarrhea, weight loss

Fever, left upper quadrant pain, explosive diarrhea, weight loss loss

4 cases;

$36 / \mathrm{M}$

Involved GI tract

Small bowel

finding

Prominent folds in the mucosa with elevated yellowish grains and nodules on the surface of the villi

\section{Duodenum \\ Duodenum \\ Rectum and sigmoid colon}

Duodenum

Terminal ileum temperature, weight loss fever, sweat, or chills (21/

Duodenum

Duodenum (30), esophagus (2), rectum (7)

Rectum

Duodenum

Duodenum

\section{Minute superficial} ulcerations

Diffuse and raised whitish lesions, 2-4 mm in diameter

Edematous, erythematous, and friable, with multiple linear and oval erosions

Erythematous macular mucosal lesions

Strictures with considerable compromise of the intestinal lumen, mucosal ulcerations, and thickening of the bowel wall (resection specimen)

Several isolated, yellow, and raised nodules of 2 $\times 4 \mathrm{~mm}$; more numerous and confluent distally

Duodenum: normal (17), fine white nodules on the mucosa (12)

Rectum: normal (3), perianal fistula (1), reduced vascular pattern (2), rectal ulcer (1) Esophagus: ulcers (2)

Loss of vascular pattern, generalized inflammation and mucosal friability;

Diffuse white nodules 2-3 $\mathrm{mm}$ in diameter; superficial erosions

Small, white nodules with surrounding

NA

Survived
Died
(32/35)

Died

Died

Survived

Died

Alive

Outcome

Died 
TABLE 1. (continued)

\begin{tabular}{|c|c|c|c|c|c|}
\hline Reference & $\begin{array}{c}\text { Age } \\
\text { y/gender }\end{array}$ & $\begin{array}{c}\text { Clinical } \\
\text { presentation }\end{array}$ & $\begin{array}{l}\text { Involved } \\
\text { GI tract }\end{array}$ & $\begin{array}{l}\text { Endoscopy/autopsy } \\
\text { finding }\end{array}$ & Outcome \\
\hline $\begin{array}{l}\text { Cappell } \\
\text { et } \mathrm{al}^{21}\end{array}$ & $14 \mathrm{~m} / \mathrm{F}$ & $\begin{array}{l}\text { Abdominal pain, severe } \\
\text { constipation, fever, } \\
\text { hepatosplenomegaly }\end{array}$ & Duodenum & $\begin{array}{l}\text { Edematous, friable, } \\
\text { thick duodenal } \\
\text { folds }\end{array}$ & Died \\
\hline $\begin{array}{l}\text { Bosch } \\
\text { et } \mathrm{al}^{22}\end{array}$ & $37 / F$ & $\begin{array}{l}\text { Fever, weight loss, } \\
\text { severe dysphagia, } \\
\text { abdominal pain }\end{array}$ & Duodenum & $\begin{array}{l}\text { Thickening of the } \\
\text { mucosal folds and } \\
\text { multiple yellow-whitish } \\
\text { nodules; }\end{array}$ & NA \\
\hline $\begin{array}{l}\text { Cappell and } \\
\text { Philogene }^{23}\end{array}$ & $22 / \mathrm{M}$ & $\begin{array}{l}\text { Diarrhea, pyrexia, night } \\
\text { sweats, malaise, weight } \\
\text { loss }\end{array}$ & $\begin{array}{l}\text { Descending } \\
\text { duodenum; } \\
\text { rectum }\end{array}$ & $\begin{array}{l}\text { Extensive coarsely } \\
\text { granular mucosa; rectal } \\
\text { aphtha }\end{array}$ & Died \\
\hline $\begin{array}{l}\text { Velasco } \\
\text { et } \mathrm{al}^{24}\end{array}$ & $29 / M$ & $\begin{array}{l}\text { Epigastric pain, nausea, } \\
\text { vomiting without } \\
\text { diarrhea or fever }\end{array}$ & Duodenum & $\begin{array}{l}\text { No significant mucosal } \\
\text { change }\end{array}$ & Alive \\
\hline Cinti et $\mathrm{al}^{8}$ & $50 / \mathrm{M}$ & $\begin{array}{l}\text { Fever and abdominal } \\
\text { pain }\end{array}$ & $\begin{array}{l}\text { Duodenum } \\
\text { and jejunum }\end{array}$ & $\begin{array}{l}\text { Numerous raised pink } \\
\text { nodules ( } 1-\text { to } 2-\mathrm{cm} \\
\text { diameter) }\end{array}$ & Survived \\
\hline $\begin{array}{l}\text { Present } \\
\text { report }\end{array}$ & $42 / M$ & $\begin{array}{l}\text { Fever, epigastralgia, } \\
\text { abdominal distention, } \\
\text { nausea, diarrhea }\end{array}$ & Duodenum & $\begin{array}{l}\text { Diffuse and scattered } \\
\text { white nodules and } \\
\text { plaques }\end{array}$ & Died \\
\hline
\end{tabular}

$N A$, Not available.

stricture (2\%), and aphthous erosions (2\%). Thus, for definitive diagnosis in symptomatic patients, especially those without typical endoscopic findings, it is essential to obtain tissue specimens for histopathologic examination and microbiologic culture.

The introduction of effective antiretroviral therapies for HIV infection and antimicrobial prophylaxis against MAC infection have had a major impact on the incidence and the clinical course of MAC infection in patients with AIDS, but patients with new or recurrent MAC infection are still encountered in clinical practice. This may occur for several reasons: the patient may be unaware of the HIV infection; lack of access to care for HIV infection; poor compliance with treatment, including prophylaxis, for MAC infection; and poor adherence to HAART, resulting in virologic failure and suboptimal immunologic recovery. ${ }^{3,6,8}$ Because GI MAC infection may be the first presentation of AIDSassociated opportunistic infection, it is essential to be alert for endoscopic findings, even in the era of effective antiretroviral therapies. Early recognition of GI MAC infection by endoscopy in HIV-infected patients and initiation of anti-MAC therapy and HAART may reduce morbidity and mortality.

\section{REFERENCES}

1. Hsieh SM, Hung CC, Chen MY, Hsueh PR, Chang SC, Luh KT. Clinical features and outcome in disseminated mycobacterial disease in AIDS patients in Taiwan. AIDS 1998;12:1301-7.
2. Chaisson RE, Gallant JE, Keruly JC, Moore RD. Impact of opportunistic disease on survival in patients with HIV infection. AIDS 1998;12: 29-33.

3. Horsburgh CR Jr, Gettings J, Alexander LN, Lennox JL. Disseminated Mycobacterium avium complex disease among patients infected with human immunodeficiency virus, 1985-2000. Clin Infect Dis 2001;33: 1938-43.

4. Horsburgh CR Jr. Mycobacterium avium complex infection in AIDS. N Engl J Med 1991;324:1332-8.

5. Palella FJ Jr, Delaney KM, Moorman AC, Loveless MO, Fuhrer J, Satten $\mathrm{GA}$, et al. Declining morbidity and mortality among patients with advanced human immunodeficiency virus infection. HIV Outpatient Study Investigators. N Engl J Med 1998;338:853-60.

6. Kaplan JE, Hanson D, Dworkin MS, Frederick T, Bertolli J, Lindegren ML, et al. Epidemiology of human immunodeficiency virus-associated opportunistic infections in the United States in the era of highly active antiretroviral therapy. Clin Infect Dis 2000;30:S5-14.

7. Michelet $C$, Arvieux C, Francois C, Besnier JM, Rogez JP, Breux JP, et al. Opportunistic infections occurring during highly active antiretroviral treatment. AIDS 1998;12:1815-22.

8. Cinti SK, Kaul DR, Sax PE, Crane LR, Kazanjian PH. Recurrence of Mycobacterium avium infection in patients receiving highly active antiretroviral therapy and antimycobacterial agents. Clin Infect Dis 2000;30:511-4.

9. Horsburgh CR Jr. The pathophysiology of disseminated Mycobacterium avium complex disease in AIDS. J Infect Dis 1999;179(Suppl 3): S461-5.

10. Strom RL, Gruninger RP. AIDS with Mycobacterium avium-intracellulare lesions resembling those of Whipple's disease. N Engl J Med 1983;309: 1323-4.

11. Gillin JS, Urmacher C, West R, Shike M. Disseminated Mycobacterium avium-intracellulare infection in acquired immunodeficiency syndrome mimicking Whipple's disease. Gastroenterology 1983;85:1187-91.

12. Caya JG, Cohen EB, Allendorph MM, Hogan WJ, Henderson LA, Reedy MT, et al. Atypical mycobacterial and cytomegalovirus infection of the 
duodenum in a patient with acquired immunodeficiency syndrome: endoscopic and histopathologic appearance. Wis Med J 1984;83: 33-6.

13. Wolke A, Meyers S, Adelsberg BR, Bottone EJ, Damsker B, Schwartz IS, et al. Mycobacterium avium-intracellulare-associated colitis in a patient with the acquired immunodeficiency syndrome. J Clin Gastroenterol 1984;6:225-9.

14. Roth Rl, Owen RL, Keren DF, Volberding PA. Intestinal infection with Mycobacterium avium in acquired immune deficiency syndrome (AIDS). Histological and clinical comparison with Whipple's disease. Dig Dis Sci 1985;30:497-504.

15. Schneebaum CW, Novick DM, Chabon AB, Strutynsky N, Yancovitz SR, Freund S. Terminal ileitis associated with Mycobacterium aviumintracellulare infection in a homosexual man with acquired immune deficiency syndrome. Gastroenterology 1987;92:1127-32.

16. Vasquez-Iglesias JL, Yanez J, Durana J, Arnal F. Infection by Mycobacterium avium intracellulare in AIDS: endoscopic duodenal appearance mimicking Whipple's disease. Endoscopy 1988;20:27980.

17. Gray JR, Rabeneck L. Atypical mycobacterial infection of the gastrointestinal tract in AIDS patients. Am J Gastroenterol 1989;84: 1521-4.

18. Connolly GM, Shanson D, Hawkins DA, Webster JN, Gazzard BG. Noncryptosporidial diarrhoea in human immunodeficiency virus (HIV) infected patients. Gut 1989;30:195-200.

19. Monsour HP Jr, Quigley EM, Markin RS, Dalke DD, Goldsmith JC, Harty RF. Endoscopy in the diagnosis of gastrointestinal Mycobacterium avium-intracellulare infection. J Clin Gastroenterol 1991;13: 20-4.

20. Cappell MS, Gupta A. Gastrointestinal hemorrhage due to gastrointestinal Mycobacterium avium intracellulare or esophageal candidiasis in patients with the acquired immunodeficiency syndrome. Am J Gastroenterol 1992;87:224-9.

21. Cappell MS, Hassan T, Rosenthal S, Mascarenhas M. Gastrointestinal obstruction due to Mycobacterium avium intracellulare associated with the acquired immunodeficiency syndrome. Am J Gastroenterol 1992;87:1823-7.

22. Bosch O, Porres JC, Martinez Quesada G, Oliva H, Gonzalez Campos C. Endoscopic appearance of a duodenal infection by Mycobacterium avium-intracellulare in AIDS. Endoscopy 1994;26:506.

23. Cappell MS, Philogene C. The endoscopic appearance of severe intestinal Mycobacterium avium complex infection as a coarsely granular mucosa due to massive infiltration and expansion of intestinal villi without mucosal exudation. J Clin Gastroenterol 1995, 21:323-6.

24. Velasco M, Flores L, Guijarro-Rojas M, Roca V. Simultaneous intestinal leishmaniasis and mycobacterial involvement in a patient with acquired immune deficiency syndrome. J Clin Gastroenterol 1998;27:271-3.

25. Bini EJ, Weinshel EH, Gamagaris Z. Comparison of duodenal with jejunal biopsy and aspirate in chronic human immunodeficiency virusrelated diarrhea. Am J Gastroenterol 1998;93:1837-40.

26. Varsky CG, Correa MC, Sarmiento N, Bonfanti M, Peluffo G, Dutack A et al. Prevalence and etiology of gastroduodenal ulcer in HIV-positive patients: a comparative study of 497 symptomatic subjects evaluated by endoscopy. Am J Gastroenterol 1998;93:935-40.

Department of Internal Medicine, National Taiwan University Hospital and National Taiwan University College of Medicine, Taipei, Taiwan; Department of Parasitology, National Taiwan University College of Medicine, Taipei, Taiwan.

Reprint requests: Chien-Ching Hung, MD, Department of Internal Medicine, National Taiwan University Hospital, 7 Chung-Shan South Rd., Taipei, Taiwan.

Copyright $@ 2005$ by the American Society for Gastrointestinal Endoscopy 0016-5107/2005/\$30.00+ 0

PII: S0016-5107(04)02786-5

\title{
Double-balloon enteroscopy for diagnosis of a Meckel's diverticulum in a patient with GI bleeding of obscure origin
}

\author{
Antonio Gasbarrini, MD, Simona Di Caro, MD, Massimiliano Mutignani, MD, \\ Giovanni Cammarota, MD, Lucia Fini, MD, Fabio Pacelli, MD, Paolo Pola, MD, \\ Giovanni Doglietto, MD, Guido Costamagna, MD, Giovanni Gasbarrini, MD
}

Rome, Italy

Standard EGD, colonoscopy, and radiologic imaging studies fail to demonstrate a source in about $10 \%$ of patients with GI bleeding.

Because the small bowel is only partially accessible with endoscopy, it is the site of most undiagnosed lesions. ${ }^{1}$ Meckel's diverticulum is the most common congenital anomaly of the GI tract (approximately 2\%-3\% of the population). It is the result of improper closure and absorption of the omphalomesenteric duct and usually is located within $100 \mathrm{~cm}$ of the ileocecal valve. There is a strong male preponderance, and $60 \%$ of patients with Meckel's diverticulum come to medical attention before 10 years of age. Heterotopic gastric or pancreatic mucosa frequently is found within the diverticulum in patients with symptoms because of the anomaly. Patients with a Meckel's diverticulum that contains heterotopic gastric mucosa $(30 \%$ of cases) are more likely to develop symptoms than those with a diverticulum that contains only intestinal mucosa. The most common complications are hemorrhage as a consequence of peptic ulceration, obstruction, intussusception, volvulus, and diverticulitis. Although the clinical, histopathologic, and radiologic features of the complications of Meckel's diverticulum are well known, the diagnosis may be difficult before surgery. ${ }^{2}$ 